\title{
THE CONSTRUCTION NON-PREFIXED VERB + SPATIAL ADVERB IN LATVIAN
}

\author{
Andra Kalnača \\ University of Latvia
}

\begin{abstract}
The status of constructions of the type non-prefixed verb + adverb with regard to expressing aspectuality (iet iekša 'to go in', vert valı $\bar{a}$ 'to open up' etc.) is one of the most interesting problems in Latvian aspectology. However, too little attention has been paid in Latvian linguistics to the use of such constructions in sentences, as well as to the lexical (spatial) meanings of adverbs and their syntactic functions. This study aims to fill that gap, taking a closer look at the ways in which constructions of the type non-prefixed verb + adverb are used in sentences, as well as at the semantics of adverbs and their role in expressing verbal aspect.

Whether a verb tends to bind with an adverbial modifier of place (a spatial adverb) when used in actual sentences is determined by verb semantics, resp. telicity, and does not have any direct bearing on the imperfective vs. perfective aspect of the verb or vice versa. Besides, adverbs are non-obligatory. The main conclusion of this study then is that the concept 'construction of the type non-prefixed verb + adverb' should be used with extreme caution with regard to verb-adverb bindings in sentences. It can, perhaps, be applied, in a very broad sense, to verbs of motion (and other telic verbs), but not to the use of all Latvian verbs in general.
\end{abstract}

Keywords: aspect, telicity, verb of motion, non-prefixed / prefixed verb, spatial adverb

DOI: https://doi.org/10.12697/jeful.2017.8.1.05

\section{Introduction}

Before focusing on the actual subject of the study a few preliminary remarks must be made about Latvian verbal aspect. The contrast between imperfective and perfective action in Latvian is expressed by means of verbal prefixes: if a verb has no prefix it expresses imperfective action and, conversely, prefixed verbs are usually perfective (in detail see, for example, Kalnača 2013 and 2014):

(1) a. kāpt 'to go up, to climb'-uz-kāpt 'to go up, to climb'

b. lasit 'to read'-iz-lasit 'to read through'

c. dziedāt 'to sing' - no-dziedāt 'to sing through' 
The perfective / imperfective opposition applies to the vast majority of Latvian verbs. Furthermore, in contrast to verbal inflectional morphology verbal prefixes and suffixes are present in the infinitive and consistently preserved in all grammatical forms. Apart from expressing perfectivity prefixes also carry spatial, temporal, quantitative etc. meanings, which can modify the lexical meaning of the verb they attach to in different ways (see section 3 for more details). All this indicates that aspectual meanings do not show full grammatical abstraction in Latvian and are rather related to the formation and functioning of verbs as lexical units (among others, Soida 2009: 227).

Imperfective aspect, the unmarked member of the aspectual opposition, is used to refer to actions as processes, while perfective aspect looks at actions as complete events or finalised processes (Matthews 1997: 171, 271, Kalnača 2013). Processual actions are not homogeneous: they may, for example, convey duration, generalisation, repeated action, etc., thus, imperfective aspect arguably has much broader and much more diverse application in language. Perfective aspect, on the other hand, helps to represent the division of real-world processes into discrete events, accentuating, as the case may be, their onsets or sequences.

In addition, Latvian permits constructions consisting of an imperfective non-prefixed verb and a spatial adverb. These constructions are mainly imperfective and have the meaning of a specific action directed at a known spatial target (Staltmane 1958: 17-21, Ahero et al. 1959: 571, Endzelīns 1971: 624, Kalnača 2003, 2013, 2014, 2015):

\section{(2) a. iet iekša ' to go in' \\ b. nākt šurp 'to come here' \\ c. kāpt pāri 'to step over' \\ d. skriet prom 'to run away'}

The status of constructions of the type non-prefixed verb + adverb with regard to expressing aspectuality (see examples (2)) is one of the most interesting problems in Latvian aspectology. Although these constructions had been discussed by the author on several occasions in the past (Kalnača 2004, 2005, 2013, 2014, 2015), the necessity to reconsider their role in expressing aspectual meanings became evident when working on the description of verbal aspect for the "Grammar of the Latvian Language" (Latviešu valodas gramatika 2013: 535-537), which involved reassessing the existing descriptive tradition with regard 
to verbal aspect. As a result, the aforementioned grammar adheres to the description traditional for Latvian linguistics (for example, Endzelins 1951, Ahero et al. 1959, Paegle 2003) in that it views the constructions in question as peripheral syntactic means of expressing imperfective aspect, mostly applicable to a semantically limited set of words - verbs of motion and spatial adverbs. At the same time, it also briefly mentions aspectual relations between such word combinations as iet iekša - ieiet iekš $\bar{a}$ 'to go in' and colloquial expressions of the type non-prefixed verb + adverb (vākties kop $\bar{a}$ 'to gather [no object]', rakstīties iekš $\bar{a}$ 'to sign in', iet cauri 'to go through', gulēt nost 'to fall asleep', taisìt augšs ' to make', etc.), which are idiomatic in nature (Kalnača 2013: 537), for example:

(3) dzivot nost 'to live very well'

\begin{tabular}{|c|c|c|c|}
\hline $\begin{array}{l}\text { [vini ] Saņem } \\
\text { [they] get.Prs.3 }\end{array}$ & $\begin{array}{l}\text { savu } \\
\text { their.ACC.M }\end{array}$ & $\begin{array}{l}v a i \\
\text { or }\end{array}$ & $\begin{array}{l}\text { bērnu } \\
\text { child.GEN.PL.M }\end{array}$ \\
\hline & dż̄̄vo & & nost. \\
\hline & $a$ & & away \\
\hline
\end{tabular}

'[They] get their welfare benefits or child care allowance and just live it up. Leeching off children.' (Kas Jauns)

It seems, however, that the exact nature of these constructions still requires further discussion, with a focus on their use in sentences, which is also what Hauzenberga-Šturma (1979), who devotes considerable space to the analysis of word combinations consisting of non-prefixed verbs and adverbs in her work, suggests, emphasising that too little attention has been paid in Latvian linguistics to their use in sentences, as well as to the lexical, resp. spatial meanings of adverbs and their syntactic functions. Addressing these points, therefore, will be the main purpose of this article.

\section{A brief note on the origin of the construction}

The view taken here is that the construction non-prefixed verb + $a d v e r b$ is the result of the natural evolution of the Latvian language (see Kalnača 2015 for more details; for other views see Kagaine and Bušs 1986, Boiko 2001, Liparte 1996 and 2001). As Wälhli (2001) points out, despite the phenomenon under consideration being seemingly similar 
to its counterparts in, for example, Livonian or Estonian (Rudzìte 1994, Boiko 2001, Metslang 2001, Klaas-Lang and Norvik 2014, Norvik 2016), neither typological comparison nor analysis of Baltic and Finnic language material give sufficient grounds to believe that the said constructions are loans. Regarding adverbs or, in Wälhli's terminology, particles appearing in such constructions Wälhli (2001: 432-434) says:

"Baltic shows a strong tendency to designate perfectivity by means of prefixes to the verb. .. The lexical material of the verb particles shows that it would be somewhat too easy to conclude that the Latvian verb particles are loans from Finnic. The situation is more complex and more thrilling than that. In our discussion of the Latvian and Livonian material we stated that almost every verb particle under consideration shows a slightly different area of distribution."

On similar grounds Matthiassen (1997) rejects the idea that these constructions could be loans from German (see, for example, Boiko 2001) - although there is some resemblance verbal aspect is expressed and functions in completely different ways in Latvian and German. Likewise, it is also perhaps revealing that when describing the influence of the Baltic-Finnic languages (Finnish, Estonian, Livonian) on the Baltic languages Breidaks (1999: 8-10) does not mention constructions of the type non-prefixed verb + adverb at all.

It should be emphasised that apart from Latvian constructions of the type non-prefixed verb + adverb are also found in Lithuanian (for example, Valiulytė 1998, Liparte 2001), Polish (for example, Holvoet 2001: 135), English (on English phrasal verbs see, for example, Halliday 2001: 207-210, Allan 2001: 125-126) and other Indo-European languages where it would be difficult to speak about any direct influence from Finno-Ugric (Comrie 1976, 93), for example:

(4) a. In Lithuanian

eiti - eiti lauk / eiti laukan 'walk - walk out'

(usually in colloquial speech and subdialects alongside the Standard Lithuanian variant išeiti 'walk out')

b. In English

eat-eat up

As the said constructions are more frequent in the Livonian subdialect of Latvian (among others Kagaine 1992, Liparte 1996 and 2001, Boiko 2001) the fact that constructions of the type non-prefixed verb + adverb are more diverse and more widespread in Latvian than they are in Lithuanian may indeed be related to influence from Livonian and 
Estonian, which cannot be said about the origin of these constructions, for they may conceivably emerge as a result of the natural development of any language.

\section{Verbal prefixes and their meanings}

Ever since Endzelīns' two-volume study on Latvian prepositions (Latyshskie predlogi 1905-1906) it has been customary in Latvian linguistics to include the parallelism between spatial verbal prefixes and adverbs in descriptions of verbal aspectual meanings (see, for example, Endzelīns and Mīlenbahs 1934, Endzelīns 1971: 622-632, 1951, Ahero et al. 1959, Paegle 2003, Soida 2009, Kalnača 2013 and 2014). Thus, Endzelīns (1971: 625-631) lists a number of Latvian prefixes and their semantically corresponding adverbs, paying little attention to the lexical meaning of verbs, see, for example, the prefix at- (examples (5)-(8) from Endzelīns 1971: 625-626):

$$
\text { at- and nost 'off, away' }
$$

a. ar tuo [nüju] varuot ... velnu

with this.INS.F [stick] can.oBL devil.ACC.M

at-gaingāt...

drive_away.INF

'they say it [the stick] can be used to ... drive the devil away'

b. Lìdz rìtam gainäja velnu

till dawn.DAT.M keep.PST.3 devil.ACC.M

nио ... kapa nuost

from grave.Gen.m away

'[they] were keeping the devil away from the grave till the dawn'

(6) at- and vală, valām 'up'

$\begin{array}{lllllll}\text { lai } & \text { netaisa } & \text { val̦ām } & \text { [kasti], } & \text { kamēr } & \text { uz } & \bar{u} \text { deņa } \\ \text { let } & \text { not_open.PRS.3 } & \text { up } & \text { [box] } & \text { while } & \text { on } & \text { water.GEN.M }\end{array}$

[tell them] not to open up [the box] while on the water'

(7) at-and atpakal 'back'

$\begin{array}{llll}\text { atpakal } & \text { nākdami, atpakal iedami } \\ \text { back come.PTCP back } & \text { go.РТCP } \\ \text { 'coming back, going back' }\end{array}$




$$
\begin{aligned}
& \text { at- and pretī, pretim 'back' } \\
& \text { dēls aurējis pretim. Kā at-aurējis... } \\
& \text { son.NOM.M howl.PTCP back as howl.PTCP } \\
& \text { 'the son howled back. As soon as [he] howled back...' }
\end{aligned}
$$

As exemplified by the prefix at- above Latvian verbal prefixes are polysemous and may correspond to different spatial adverbs depending on the context, i.e. their use in actual sentences, and the semantics of the verb they attach to (the opposite directions 'away' and 'hither' in the above examples, returning 'back', opening up a vessel).

Besides, it must be emphasised that while spatial meanings are not the only meanings verbal prefixes have, they are the only ones displaying prefix-adverb correspondences. For example, in addition to the above the prefix at- can also express amount or extent, i.e. short (inchoative) action (examples (9)) (Vulāne 2013: 280), partly accomplished action / action applied to the subject or object to a certain extent (examples (10)), fully accomplished action (examples (11)), action done to excess or until no longer desired (examples (12)) (Soida 2009: 248-254).

(9) a. at-skanēt 'to go off (of a sound)'

b. at-spìdēt 'to flash, begin to shine'

c. at-vizēt 'to begin to shimmer, shine'

(10) a. at-mirt 'to die off, atliet 'to pour off'

b. at-kost [gabalu] 'to bite off [a piece]'

c. at-griezt [siera šksèli] 'to cut off [a slice of cheese]'

(11) a. at-dzist 'to cool down'

b. at-mosties 'to wake up'

c. at-veldzēt 'to refresh'

(12) a. at-dzerties 'to drink one's fill'

b. at-ēsties 'to eat one's fill'

c. at-sēétities 'to sit it out'

Soida (2009: 259) also distinguishes the meaning of a change of state: 
"Verbs derived by means of the prefix at- denote processes that result in regainment of an earlier state, feature or object, for example ataugt 'to regrow', atdzimt 'to be born again', atsilt 'to get warm again', atdzìvoties 'to revive [no object]', atveseļoties 'to recover [from illness]."

Which of the meanings - spatial, amount / extent or change of state is actually realised depends on the specific verb the prefix binds with and on the communicative situation.

A possible explanation for the existence of semantic parallelism between prefixes and adverbs is that they may have common historical origins - all prefixes originate from prepositions, which in their turn may share origins with adverbs (Rudzìte 1968: 207-224).

\section{The syntactic status of the construction verb + adverb}

\subsection{A brief overview of the terminological debate}

The tradition to speak about constructions of the type (nonprefixed) verb + adverb when describing correspondences between spatial verbal prefixes and adverbs was established by Staltmane (1958: 17-21), who classified them as analytical constructions. This choice of wording means recognising that the adverb has grammaticalised, i.e. lost its syntactic and semantic independence, turning, in functional terms, into a function word, which simply does not hold true for Latvian either semantically or syntactically, because verb and adverb combinations can vary quite freely depending on the information that needs to be communicated. Perhaps for this reason the concept of analytical constructions has never been further elaborated in subsequent work on Latvian verbal aspect (see, for example, Paegle 2003, Soida 2009, Kalnača 2013 and 2014).

Although the term construction in the broad sense of "units, i.e. word combinations that make up larger units, i.e. sentences" has survived in research on verbal aspect until very recently (Matthews 1997: 71, Crystal 1997: 86, also see Mathiassen 1997, Toop 2001, Paegle 2003, Soida 2009, Kalnača 2013 and 2014, Horiguchi 2016), whether such constructions are distinct aspect expressing units and what aspectual meanings they actually have remains a matter of some controversy to this day.

For example, Holvoet (2001: 146) states that "the addition of a local adverb to a simple verb is a lexical process without aspectual function 
(they can therefore be added to inherently perfective simple verb as well)", while Kalnača (2013, 2014 and 2015) and Horiguchi (2016) refer to combinations of non-prefixed verbs and adverbs as representing the periphery (or even the periphery of the periphery) of aspectual meaning expression.

Linguists' opinions also differ as to whether a non-prefixed verb combined with an adverb (kāpt lejā 'to go down [the stairs]', iet iekšs $\bar{a}$ 'to go in', likt kopa ' 'to put together') expresses the imperfective (Paegle 2003, Soida 2009, Kalnača 2013 and 2014) or the perfective (Ahero et al. 1959, Kalme and Smiltniece 2001) aspect. Although there are valid arguments in favour of both positions one has to agree with Horiguchi (2016) who, having carried out an in-depth analysis of combinations of verbs with the adverb nost 'off, away', points out that depending on the communicative situation and context one and the same combination can express either the imperfective (example (13)) or the perfective aspect (example (14)), which makes one wonder if in that case it is possible at all to speak about distinct, grammaticalised verb + adverb constructions with regard to expressing aspect in Latvian (on similar problem in Lithuanian dialects see Girdenis, Kačiuškienè 1986, and also Liparte 2001).

$\begin{array}{llll}\text { No } & \text { Kiñas } & \text { tirgus } & \text { pamazām } \\ \text { from } & \text { China.GEN.F } & \text { market.GEN.M } & \text { little_by_little } \\ \text { ejam } & \text { prom. } & \\ \text { move.PRS.1PL } & \text { away } & \end{array}$

'Little by little, we are moving away from the Chinese market.' (www.db.lv)

(14) Vai obligāti jāstrāàā mēnesis,

$\begin{array}{lllll}\text { ja } & \text { eju } & \text { prom } & \text { no darba? } \\ \text { if } & \text { go.PST.1SG } & \text { away } & \text { from } & \text { job.GEN.M }\end{array}$

'Do I have to work for the [notice] month if I am quitting my job?' (www.delfi.lv)

Thus, the whole discussion, in fact, centres around the question of the extent to which the adverb has grammaticalised. Either it has partly lost its lexical meaning and is used as a conveyor of grammatical meaning, a function word with no syntactic function of its own, or it is an independent lexical word functioning as an adverbial modifier of place. 
There is an interesting inconsistency in the "Grammar of Contemporary Standard Latvian" (Mūsdienu latviešu literārās valodas gramatika, see Ahero et al. 1959: 571), which mentions a special kind of imperfective forms of verbs: "combinations of a non-prefixed verb with an adverb where the latter is semantically similar to the prefix of the corresponding perfective verb, for example pārcelt - celt pāri 'to take across"”.

Namely, although it refers to imperfective forms consisting of a nonprefixed verb and an adverb the status of the adverb is not made clear. The choice of terminology, however, suggests that what binds with the verb here is not an adverb but rather some kind of a fully formalised element, which is an essential component of the given grammatical form.

Constructions of the type non-prefixed verb + adverb have also been described as particle verbs (Latvian partikulverbs) in Latvian linguistics (see, for example, Wälhli 2001, Liparte 1996 and 2001) based on a broader interpretation of the term particle incompatible with Latvian linguistic tradition. In many grammars, especially English ones, the term particle is used to denote all kinds of indeclinable parts-of-speech and grammatical elements (see definitions given by, for example, Matthews 1997: 267, Crystal 1997: 279-280). In Latvian grammar, however, the term particle refers to a specific indeclinable part-of-speech, which has nothing to do with verb government - verbs do not determine the use of particles, rather particles apply to the contents of whole sentences (Skujina 2007: 288). Furthermore, when applied to Latvian the term particle verb seems to suggest that there exists a special group of verbs that can only be realised semantically and syntactically in conjunction with certain grammaticalised elements or function words, i.e. particles (the same problem arises if the term phrasal verb is applied to Latvian, see, for example, Holvoet 2001). However, it is clear that when used in sentences such verbs can bind with adverbs that have a definite meaning, point to the target of the respective spatial action and are relevant to the contents of the whole sentence.

\subsection{The status of adverbs in the construction}

When considered in context spatial adverbs often turn out to be typical adverbial modifiers of place rather than grammaticalised correlates of verbal prefixes, cf. for example: 
(15) Bija vasaras nakts, mēs sēdējām ārā bārāa, un es teicu [draudzenei]:

\begin{tabular}{|c|c|c|c|c|}
\hline $\begin{array}{l}\text { ejam } \\
\text { go.IMP.1PL }\end{array}$ & $\begin{array}{l}\text { augš } \overline{\boldsymbol{a}} \text {. } \\
\text { up(stairs) }\end{array}$ & & & \\
\hline $\begin{array}{l}M \bar{e} s \\
\text { we.NOM }\end{array}$ & $\begin{array}{l}\text { uzgājāmm } \\
\text { go.PST.1PL }\end{array}$ & $\begin{array}{l}\text { dzīvoklī } \\
\text { apartment.LOC.M }\end{array}$ & $\begin{array}{l}\text { un } \\
\text { and }\end{array}$ & $\begin{array}{l}\text { nodejojām } \\
\text { dance.PST.1PL }\end{array}$ \\
\hline $\begin{array}{l}\text { visu } \\
\text { whole.ACC. }\end{array}$ & $\begin{array}{l}{[m \bar{u} z i k a} \\
{[\text { music] }}\end{array}$ & $\begin{array}{l}\text { albumu } \\
\text { album.ACC.M }\end{array}$ & $\begin{array}{l}\text { no } \\
\text { from }\end{array}$ & $\begin{array}{l}A \operatorname{lid} z Z . \\
\text { A to } Z\end{array}$ \\
\hline
\end{tabular}

'It was a summer night, we were sitting at an outdoor bar and I said [to my girlfriend]: let's go up(stairs). We went up to the apartment and danced through the whole [music] album, from A to Z.' (Diena)

The adverb augš $\bar{a}$ ' up' here expresses direction (while also providing information that the apartment in question is on the second floor of the building or higher) and functions as an adverbial modifier of place. It is not, however, a correlate of the prefix $u z$-, i.e. it does not seem possible to maintain in this case that there exists an obligatory construction ejam augš $\bar{a}$ 'let's go up(stairs)' corresponding to the prefixed verb uzejam 'let's go up'. The adverb, resp. adverbial modifier augša 'up' is not indispensable for the contents of the sentence - even if it were removed the contents of the sentence would still be comprehensible from the context:

(16) Bija vasaras nakts, mēs sēdējām ārā bārāa, un es teicu [draudzenei]: ejam.

go.IMP.1PL

'It was a summer night, we were sitting at an outdoor bar and I said [to my girlfriend]: let's go.'

The sentence would work equally well with a prefixed verb uz-ejam 'let's go up' followed by the spatial adverb augš $\bar{a}$ 'up':

(17) Bija vasaras nakts, mēs sēdējām ārā bārā, un es teicu [draudzenei]:

$\begin{array}{ll}\text { uz-ejam } & \text { augšă. } \\ \text { PREF-go.IMP.1PL } & \text { up(stairs) }\end{array}$

'It was a summer night, we were sitting at an outdoor bar and I said [to my girlfriend]: let's go.'

Besides, both the imperfective verb ejam 'let's go' and the perfective uz-ejam 'let's go up' can be followed by a prepositional phrase or even a noun in the locative case as an adverbial modifier of place without affecting the contents of the sentence: 
(18) Bija vasaras nakts, mēes sēdējām ārā bārā, un es teicu [draugiem]: ejam/uz-ejam uz dzīvokl-i/ dzīvokl-ī. go.IMP.1PL / PREF-go.IMP.1PL to apartment-ACC.SG.M / -LOC.SG.M 'It was a summer night, we were sitting at an outdoor bar and I said [to my friends]: let's go / let's go up to the apartment.

This variability of sentence structure indicates that it really is impossible to speak about standardised verb and adverb constructions as analogues of grammatical forms. What is possible though is to speak about adverbial modifiers of place, which similarly to other adverbial modifiers can appear in the guise of "different forms of nouns, prepositional phrases, adverbs" (Lokmane 2013: 765).

\section{Adverbial modifiers as sentence expanders}

The nature of adverbial modifiers as non-obligatory elements that can be used to expand the conceptual structure of sentences (see Lokmane 2013: 711) is clearly visible in constructions involving nonprefixed verbs and adverbs. Spatial adverbs functioning as adverbial modifiers point to the direction, target of the respective action and are usually placed to the right of the verb, resp. predicate (see Lokmane 2013: 765):

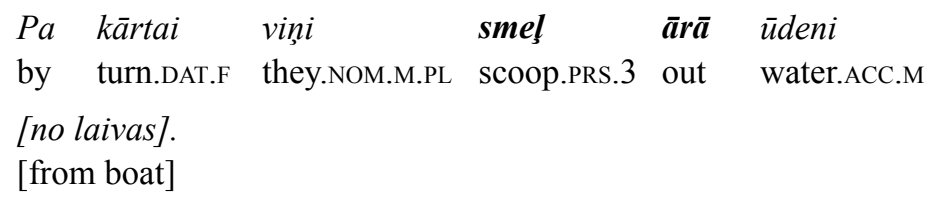

'They are scooping water [from the boat] one by one.' (Ikstena 2011)

(20) Viņ̌ $\quad$ găja lejā

he.NOM.M go.PST.3 down by stairs.DAT.PL.F

'He was going down the stairs.' (Jonevevs)

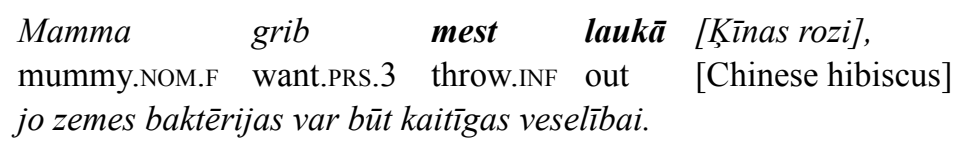

'Mummy wants to throw [the Chinese hibiscus] away, because soil bacteria can be bad for health.' (Ikstena 2007) 
Besides, as has already been mentioned, apart from spatial adverbs other elements - prepositional phrases (ejam uz dzivivokli 'let's go to the apartment') and nouns in the locative case (uzejam dzivokli 'let's go up to the apartment') - can also function as adverbial modifiers of place (see also Soida 2009: 236-237).

Despite being non-obligatory, adverbial modifiers are usually important for the contents of the sentence they are used in. If the direction of the movement 'from upstairs to downstairs' was not explicitly specified in example (20) Viňš gāja lejā pa kāpnēm 'He was going down the stairs' it would not be clear if the person referred to was ascending or descending the stairs. Such spatial nuances, however, are quite unrelated to the imperfective vs. perfective aspect of the verb, which is additionally confirmed by the fact that in Latvian adverbs are often used with prefixed verbs (see Comrie 1976: 91, Holvoet 2001: 132-158, Paegle 2003: 134, Kalnača 2013: 537, 2014: 98-99):

$\begin{array}{lll}\text { Viňš } & \text { pa-skatījōs } & \text { apkārt. } \\ \text { he.NOM.M } & \text { PREF-look.PST.3 } & \text { around }\end{array}$

'He looked around.' (Jonevevs)

(23)

$\begin{array}{llllll}\text { Cerams, } & k a & \text { vini } & a k u & \boldsymbol{a i z}-\boldsymbol{v} \overline{\boldsymbol{r}} \boldsymbol{a} & \text { ciet. } \\ \text { hopefully } & \text { that } & \text { they.NOM.PL.M } & \text { well.ACC.F } & \text { PREF-close.PST.3 } & \text { up }\end{array}$

'Hopefully, they closed that well.' (www.tvnet.lv)

(24) Ilze

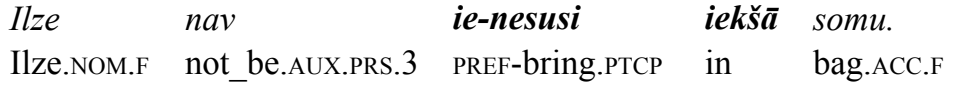

'Ilze hasn't brought the bag in.' (Gaile)

Prefixed verbs usually denote perfective action (where prefixed verbs have non-prefixed correlates) regardless of adverbs; thus, adverbial modifiers used with spatial prefixed verbs are important for accurate expression of spatial meaning without affecting verbal aspect.

It should be borne in mind, however, that in Latvian such adverbs are only used in sentences as adverbial modifiers if the predicate is (or contains) a telic verb, i.e. a verb denoting a purposeful action or action having a definite endpoint (see, for example, Matthews 1997: 373, Soida 2009: 236). Telic verbs are semantically very diverse and include verbs of physical action and verbs of motion (examples (25)), verbs of non-physical motion (examples (26)) and purposeful mental activity (examples (27)). 
(25) a. iet 'to walk'

b. skriet 'to run'

c. mazgāt 'to wash'

d. tìrìt 'to clean'

(26) a. pirkt 'to buy'

b. precēt 'to marry'

(27) a. lasit 'to read'

b. skatīties 'to watch'

Semantically, these verbs may need a (non-obligatory) adverbial modifier to specify the direction or target of the action. In Latvian, such adverbial modifiers (which take the form of spatial adverbs) mainly bind with verbs of motion. In colloquial speech - also with verbs of purposeful non-physical motion and mental activity, in which case they tend to convey either positive or negative evaluation and are not stylistically neutral (Kalnača 2013: 537 and 2014: 100):

(28) Ātrāk gribējās tikt laukumā [pēc traumas].

Nīku $\overline{\boldsymbol{a}} \boldsymbol{r} \overline{\boldsymbol{a}}$ no bezdarbības.

wither.PST.1SG out from idleness.GEN.F

'I wanted to get back on the field as soon as possible [after a trauma]. I was withering away from idleness.' (Ieva)

Telic verbs can bind with spatial adverbs regardless of whether they are prefixed or not, i.e. telicity and imperfectivity / perfectivity are not directly related (in detail see, for example, Borik, Reinhart 2004). In a sentence, a spatial adverb can appear with a non-prefixed, as well as with a prefixed verb, for example (see also examples (22)-(24)):

(29) a. skriet prom - aiz-skriet prom 'to run away'

b. skriet šurp - at-skriet šurp 'to run hither'

c. kāpt augša $\bar{a}-u z-k \bar{a} p t$ augša ' to go up, climb up'

d. kāpt lejā-no-kāpt lejā 'to go down, climb down' 


\section{Conclusions}

Whether a verb tends to bind with an adverbial modifier of place (a spatial adverb) when used in actual sentences is determined by verb semantics, resp. telicity and does not have a direct bearing on the imperfective vs. perfective aspect of the verb or vice versa, cf. skriet prom aizskriet prom 'to run away'. Besides, adverbs are non-obligatory.

The concept 'construction of the type non-prefixed verb + adverb' should be used with extreme caution with regard to verb-adverb bindings in sentences. It could be applied, in a very broad sense, to verbs of motion (and other telic verbs), but not to the use of all Latvian verbs in general.

Verbal prefixes are the principal means of expressing the imperfective / perfective aspect in Latvian. However, apart from perfectivity each prefix also expresses other, for example, spatial, quantitative, etc. meanings, i.e. all prefixes are polysemous.

Spatial meanings of some verbal prefixes in Latvian correspond to those of spatial adverbs. The latter can appear in sentences next to verbs as adverbial modifiers of place. Depending on the lexical meaning of the verb and the intended sentence contents one and the same prefix may correspond to different spatial adverbs.

The use of verbs and adverbs in sentences has not grammaticalised in Latvian either into distinct constructions or forms.

\section{Address:}

Andra Kalnača

Latvijas Universitāte

Humanitāro zinātņu fakultāte

Latvistikas un baltistikas nodaļa

Latviešu un vispārīgās valodniecības katedra

Visvalža iela 4a

LV-1050 Rīga, Latvia

E-mail: andra.kalnaca@lu.lv

\section{Abbreviations}

1, 2, 3 - persons, ACC - accusative, AUX - auxiliary, DAT - dative, DEB debitive, $\mathrm{F}$ - feminine, GEN - genitive, INS - instrumental, LOC - LOCATIVE, $\mathrm{M}$ - masculine, NOM - nominative, OBL - oblique mood, Q - question particle, PL - plural, PREF - prefix, PRS - present, PST - past, SG - singular 


\section{References}

Ahero, Antonija et al. (1959) Mūsdienu latviešu literārās valodas gramatika. (I. Fonētika un morfologiija). Rīga: Latvijas PSR Zinātņu akadēmijas izdevniecība.

Allan, Keith (2001) Natural language semantics. Oxford: Blackwell Publishers.

Boiko, Kersti (2001) "Igauņu valodas savienojuma verbi un to atbilsmes latviešu valodā (izpētes stāvoklis)". Linguistica Lettica 8, 180-193.

Borik, Olga and Tanya Reinhart (2004) "Telicity and perfectivity: Two independent systems”. In László Hunyadi, György Rákosi, and Enikő Tóth, eds. Proceedings of LOLA 8 (Symposium on Logic and Language), 13-34. Debrecen, Hungary.

Breidaks, Antons (1999) Ievads baltu valodniecībā. 2. dą̧a. Daugavpils: Saule.

Comrie, Bernard (1976) Aspect. Cambridge: Cambridge University Press.

Crystal, David (1997) A Dictionary of linguistics and phonetics. Oxford: Blackwell Publishers.

Dahl, Östen (1985) Tense and aspect systems. Oxford: Basil Blackwell.

Dahl, Östen (2000) "The tense-aspect systems of European languages in a typological perspective". In Östen Dahl, ed. Tense and aspect in the languages of Europe, 3-25. Berlin / New York: Mouton de Gruyter.

Endzelīns, Jānis (1951) Latviešu valodas gramatika. Rīga: Latvijas Valsts izdevniecība.

Endzelin, Janis (1971) “Latyshskie predlogi”. Darbu izlase I, 307-655. Rīga: Zinātne. [1st edn.: Jur'ev, 1905-1906]

Endzelīns, Jānis and Kārlis Mīlenbachs (1934) Latviešu gramatika. Rīga: Valters un Rapa. [1st edn.: Rīga: K. I. Sichmaņa apgahdiba, 1907]

Girdenis, Aleksas and Genovaite Kačiuškienè (1986) "Paraleliniai reiškiniai latvių ir šiaurinių lietuvių veiksmažiodžio sistemose". Kalbotyra 37(1), 21-27.

Halliday, Michael A. K. (2001) An introduction to functional grammar. 9th edn. London: Arnold.

Hauzenberga-Šturma, Edīte (1979) "Zur Frage des Verbalaspekt im Lettischen". Zeitschrift für vergleichende Sprachforschung 93. Göttingen: Vandenhoeck \& Ruprecht, 279-316.

Holvoet, Axel (2001) Studies in the Latvian verb. Kraków: Wydawnictwo universitetu Jagiellońskiego.

Horiguchi, Daiki (2016) "Priedēkḷa un adverba atbilsme konstrukcijā "pamatverbs + adverbs" latviešu valodā". In Andra Kalnača, Ilze Lokmane, and Daiki Horiguchi, eds. Valoda: nozìme un forma. 7. Gramatika un sazinga, 31-40. Rīga: LU Akadēmiskais apgāds.

Kagaine, Elga (1992) Semantiskie dialektismi Ziemeļrietumvidzemes izloksnēs. Rīga: Zinātne.

Kagaine, Elga and Ojārs Bušs (1985) "Dažas baltu un Baltijas somu valodu semantiskās paralēles”. Baltu valodas senāk un tagad, 35-44. Rīga: Zinātne.

Kalme, Vilma and Gunta Smiltniece (2001) Latviešu literārās valodas morfologija un vārddarināšana, Liepāja: LiePA.

Kalnača, Andra (2004) "Darbības vārda veida kategorijas realizācija latviešu valodā". Linguistica Lettica 13, 5-34. 


\section{Andra Kalnača}

Kalnača, Andra (2005) "A study of aspect correspondences between Latvian and Finnish”. Kalbu studijos / Studies about Languages 7, 26-29.

Kalnača, Andra (2013) “Darbības vārds (verbs)”. In Daina Nītiņa and Juris Grigorjevs, eds. Latviešu valodas gramatika, 456-564. Rīga: LU Latviešu valodas institūts.

Kalnača, Andra (2014) A typological perspective on Latvian grammar. Warsaw / Berlin: De Gruyter Open.

Kalnača, Andra (2015) "Konstrukcijas bezpriedēkļa verbs + adverbs un somugru ietekme latviešu valodā". Kalbos istorijos ir dialektologijos problemos 3, 175-185.

Klaas-Lang, Birute and Miina Norvik (2014) "Balti areaali tüpoloogilisi sarnasusi morfosüntaksi valdkonnas". Keel ja Kirjandus 8-9, 590-608.

Liparte, Evija (1996) "Par dažiem partikulverbiem un to lietojumu Engures un Mērsraga izloksnē". Baltu filologija VI, 30-36.

Liparte, Evija (2001) "La. nost vs. malā vs. zemē un lie. žemèn vs. šalin semantiskās attieksmes literārajā valodā un izloksnēs". Linguistica Lettica 8, 151-179.

Lokmane, Ilze (2013) "Vienkārša teikuma formālā (strukturālā) organizācija". In Daina Nītiņa and Juris Grigorjevs, eds. Latviešu valodas gramatika, 710-766. Rīga: LU Latviešu valodas institūts.

Matthews, Peter H. (1997) The concise dictionary of linguistics. Oxford: Oxford University Press.

Matiassen, Terje (1997) A short grammar of Latvian. Columbus, Ohio: Slavica Publishers, INC.

Metslang, Helle (2001) "On the development of the Estonian aspect: The verbal particle ära". In Östen Dahl and Maria Koptjevskaja-Tamm, eds. The Circum-Baltic languages. Typology and contact, vol. 2: Grammar and typology, 443-480. (Studies in Language Companion Series 55.). Amsterdam/Philadelphia: John Benjamin Publishing Company.

Norvik, Miina (2016) "Research into Livonian syntax: The results of previous studies and the tasks ahead". Eesti ja soome-ugri keeleteaduse ajakiri. Journal of Estonian and Finno-Ugric Linguistics 7 (1), 177-201.

Paegle, Dzintra (2003) Latviešu literārās valodas morfologija. Rīga: Zinātne.

Rudzīte, Marta (1994) "Latviešu un lībiešu valodas savstarpējā ietekme". Lībieši 288-319. Rīga: Zinātne.

Skujiņa, Valentīna, ed. (2007) Valodniecības pamatterminu skaidrojošā vārdnīca. Rīga: LU Latviešu valodas institūts.

Soida, Emīlija (2009) Vārddarināšana. Rīga: LU Akadēmiskais apgāds.

Staltmane, Velta (1958) "Verbu veidi mūsdienu latviešu literārajā valodā". LPSR ZA Valodas un literatūras institūta raksti VII, 5-47. Rīga: Zinātne.

Toops, Gary H. (2001) "The grammar of "paraphrastic imperfectives" in Latvian and Upper Sorbian”. Slavic and East European Journal 45 (1), 96-113.

Valiulytė, Elena (1998) Dabartinès lietuviu kalbos sintaksiniai sinonimai. Vilnius: Mokslo ir enciklopedijų leidybos institutas.

Vulāne, Anna (2013) "Vārddarināšana". In Daina Nīinna and Juris Grigorjevs, eds. Latviešu valodas gramatika, 190-299. Rīga: LU Latviešu valodas institūts. 
Wälhli, Bernhard (2001) "Lexical evidence for the parallel development of the Latvian and Livonian verb particles". In Östen Dahl and Maria Koptjevskaja-Tamm, eds. The Circum-Baltic languages. Typology and contact, vol. 2: Grammar and typology, 413-442. (Studies in Language Companion Series 55.) Amsterdam/Philadelphia: John Benjamin Publishing Company.

\section{Corpora Sources}

Diena (newspaper)

Gaile, Inga (2016) Stikli. Rīga: Dienas Grāmata.

Ieva (weekly)

Ikstena, Nora (2007) Esamība ar Regīnu. Rīga: Dienas Grāmata.

Ikstena, Nora (2011) Vìrs zilajā lietusmètelītī. Rīga: Dienas Grāmata.

Joņevs, Jāni (2014) Jelgava 1994. Rīga: Mansards.

Kas Jauns (weekly)

$w w w . d b . l v$ (news portal)

$w w w . d e l f i . l v$ (news portal)

Kokkuvõte. Andra Kalnača: Konstruktsioon prefiksita verb + kohamäärsõna läti keeles. Üks läti keele aspektoloogia huvitavamaid küsimusi on konstruktsioonide prefiksita verb + adverb staatus aspekti väljendamisel (nt iet iekš $\bar{a}$ 'sisse minema', celt pāri 'üle tõstma'). Siiski pole läti keeleteaduses pööratud piisavalt tähelepanu selle konstruktsiooni kasutamisele lauses ega adverbi leksikaalsele, s.o lokaalsele tähendusele ja süntaktilistele funktsioonidele. Tähtis on rõhutada, et lokaalse tähendusega adverbi lausesse liitmise tingib verbi semantika, s.o teelisus. Verbi imperfektiivsusel/perfektiivsusel pole sellega otsest seost, vrd skriet prom - aizskriet prom 'minema jooksma'. Sealjuures pole adverbi kasutamine koos verbiga kohustuslik; samuti võib adverb liituda prefiksiga verbile. Sellepärast tuleb mõistet "konstruktsioon prefiksita verb + kohamäärsõna" kasutada väga ettevaatlikult, kui juttu on verbi ja adverbi liitumisest lauses. Üldjoontes võib seda mõistet kasutada liikumisverbide (ja teiste teeliste verbide) kohta, aga mitte kõigi läti keele verbide kohta, sest läti keele verbide ja adverbide kasutamine lauses ei ole grammatiseerunud ei konstruktsioonide ega eraldiseisvate vormidena.

Märksõnad: verbi aspekt, teelisus, adverb, liikumisverb, prefiksita/prefiksiga verb 